Article

\title{
Energy Utilization of Spent Coffee Grounds in the Form of Pellets
}

\author{
Radovan Nosek ${ }^{1, *}$, Maw Maw Tun ${ }^{2}$ (D) and Dagmar Juchelkova 2 (D) \\ 1 Department of Power Engineering, Faculty of Mechanical Engineering, University of Žilina, Univerzitna 1, \\ 010-26 Žilina, Slovakia \\ 2 VŠB-Technical University of Ostrava, 17, Listopadu 2172/15, 70800 Ostrava-Poruba, Czech Republic; \\ maw.maw.tun.st@vsb.cz (M.M.T.); dagmar.juchelkova@vsb.cz (D.J.) \\ * Correspondence: radovan.nosek@fstroj.uniza.sk; Tel.: +46-222-46-04
}

Received: 7 February 2020; Accepted: 4 March 2020; Published: 6 March 2020

check for updates

\begin{abstract}
Nowadays it is important to limit the use and combustion of fossil fuels such as oil and coal. There is a need to create environmentally acceptable projects that can reduce or even stop greenhouse gas emissions. In this article, we dealt with the objectives of energy policy with regard to environmental protection, waste utilization, and conservation of natural resources. The main objective of the research was to assess the possibility of the use of spent coffee grounds (SCG) as fuel. As a part of the solution, the processing of coffee waste in the form of pellets, analysis of calorific value and combustion in the boiler were proposed. The experiments were done with four samples of pellets. These samples were made from a mixture of wood sawdust and spent coffee grounds with ratio 30:70 (wood sawdust: spent coffee grounds), 40:60, 50:50 and 100\% of spent coffee grounds. The calorific values were compared with wood sawdust pellets (17.15 MJ.kg-1) and the best lower calorific value of $21.08 \mathrm{MJ} \cdot \mathrm{kg}^{-1}$ was measured for $100 \%$ of spent coffee grounds. This sample did not achieve the desired performance during the combustion in the boiler due to the low strength of the sample.
\end{abstract}

Keywords: spent coffee grounds; sawdust; pellets; calorific value; combustion

\section{Introduction}

In recent years, renewable energy has come to the forefront and biomass is the world's fourth-largest energy source. One of the main problems of biomass grown primarily for energy use is that it displaces the cultivation of conventional crops intended to provide food to the population. Thus, the use of waste biomass, for example, sawdust, straw, etc., is much more advantageous. Renewable energy sources are a means of reducing greenhouse gases and alternative forms of biomass also fall into this category. Generally, alternative biomass sources form unused residues of food processing, which often end up unused as waste in landfills. Spent coffee ground is included in the category of waste biomass. Therefore, the recycling of waste to energy and value-added products is one effective way to solve the problem where many countries face a serious challenge in dealing with the huge amount of waste generated daily due to their increasing populations, industrial growth, and human consumption [1] as well as in dealing with the loss of valuable resources from waste and environmental degradation [2]. Spent coffee ground (SCG) constitutes a large number of organic compounds (more than 1000 individual compounds) such as proteins, carbohydrates, tannins, fibers, caffeine, cellulose, non-protein nitrogenous, fatty acids, amino acids, polyphenols, minerals lignin and polysaccharides [1]. The lower heating value of wet SCG accounts for approximately $8.4 \mathrm{MJ} . \mathrm{kg}^{-1}$ [3] while the lower calorific values of dried SCG range between 19.3-24.9 MJ.kg ${ }^{-1}[1]$. 
Nowadays, there are a variety of options for the utilization of SCG in the field of agriculture and numerous possibilities for converting SCG to biofuels. The most recent technologies for valorization of SCG include anaerobic digestion, pyrolysis, liquefaction or gasification, oil extraction, fermentation [4] and other technologies for value-added products from SCG such as composting, adsorbents, antioxidants and nutrients. Atabani et al. reported that SCG can be recycled in different ways to produce various types of biofuels such as biohydrogen, biobutanol, biodiesel, fuel pellets, bio-oil, bioethanol, biogas and hydrocarbon fuels, or value-added products such as bioactive compounds for food, pharmaceutical, cosmetic and chemical industries and antioxidants and anti-tumor activities, adsorbents, composting, co-composting, vermicomposting, nanocomposites, biopolymers, creams-scrubs, soaps and detergents, odor control, textile, facile preparation of pyrolytic carbon as anode in sodium-ion battery, inks and screen painting, yarn, and pulp and paper production [1].

The recent research studies underlined the valorization of SCG as a valuable source of phenolic compounds and bioenergy [5], the integration of chlorogenic acid recovery and bioethanol production from SCG [4], the co-production of biodiesel and bioethanol from SCG [6,7], the coffee oil extraction from SCG using four solvents and prototype-scale extraction [8] and the production of bio-oil and biochar from the defatted SCG by slow pyrolysis [6]. The high calorific value of spent coffee grounds (SCG) has the potential for producing refuse-derived fuel (RDF), however the burning of pure SCG pellets can lead to low boiler efficiency resulting in increased particle emissions, thus additional material is required to produce good quality pellets [9]. Therefore, the research studies highlight the utilization of waste paper and coffee residue for briquette production [8], production of the carbonized briquettes from Rain tree (Samanea Saman) and SCG/tea waste [10], analysis of the effect of mixing SCG and coffee silverskin (CS) on the quality of pellet fuel produced [11] and production of the eco-fuel briquettes with $32 \%$ spent coffee ground, $23 \%$ coal fines, $11 \%$ sawdust to benefit lower toxic emissions compared to fossil fuel [12].

Likewise, in the last decade, a great deal of research has been conducted to burn waste biomass in various boilers, for example, for the analysis of the combustion tests in a commercial residential wood pellet boiler with a pure SCG pellet, a blended pellet (50\% SCG and 50\% sawdust) and a pure pine wood pellet [13], for the fuel and combustion test in a small boiler $(6.5 \mathrm{~kW})$ with SCG [2], the combustion tests of wood pellet on a fixed bed reactor with various conditions [14], and the combustion test of a fluidized bed boiler with fuel of a normal sold waste and mixing with animal wastes [15]. The combustion of straw, olives, tomatoes, cocoa beans, etc., achieved a relatively high boiler efficiency, but the problem is the emerging ash with a relatively low melting point. It is necessary to limit the clogging of the heat exchanger. Mixing these waste biofuels with wood becomes very advantageous, thus avoiding this undesirable phenomenon. By burning this biofuel, we would be able to reduce waste and obtain a renewable energy source at the same time.

Therefore, the study dealt with the objectives of energy policy with regard to environmental protection, waste utilization and conservation of natural resources in order to assess the possibility for the use of spent coffee grounds (SCG) as a fuel and to propose the processing of coffee waste in the form of pellets, analysis of calorific value and combustion in the boiler. In this article, the technical feasibility of producing biofuel from SCG is evaluated. Additionally, the experimental combustion of produced samples with the content of SCG was performed and the measurement of emissions from tests is examined.

\section{Materials and Methods}

In this research sawdust and SCG (Figure 1a,b) with moisture contents ranging from $45 \%-55 \%$ were used as input material. There was a risk of degradation of SCG with such a high water content, therefore, the moisture was reduced to $6.50 \%$ by drying in a laboratory oven at $100{ }^{\circ} \mathrm{C}$ for $12 \mathrm{~h}$. 


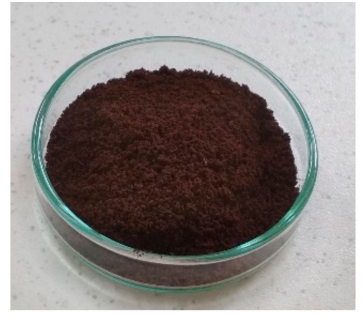

(a)

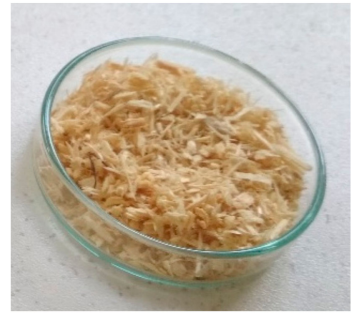

(b)

Figure 1. Input material: (a) spent coffee grounds and (b) sawdust.

The SCG was mixed with an appropriate amount of sawdust and the prepared material was then used to produce pellets in a vertical pellet press. The samples were made in the following proportions: $100 \%$ of spent coffee grounds, 50/50, 40/60 and 30/70 of SCG/sawdust, respectively.

Pelleting of each sample took approximately three minutes. Due to the low strength of the pellets, the procedure was usually repeated three times. Approximately $5 \mathrm{~kg}$ of samples (pellets) were made from each type of material mixture.

In the case of samples composed of $100 \%$ SCG, even after six repeated attempts and several moisture changes, pellets of the desired shape were not formed. The samples were soft and disintegrating. A similar result was obtained for the sample containing $50 \%$ of SCG and $50 \%$ of sawdust, but the pellets had a better cylindrical shape compared to the sample with 100\% SCG (Figure 2a,b).

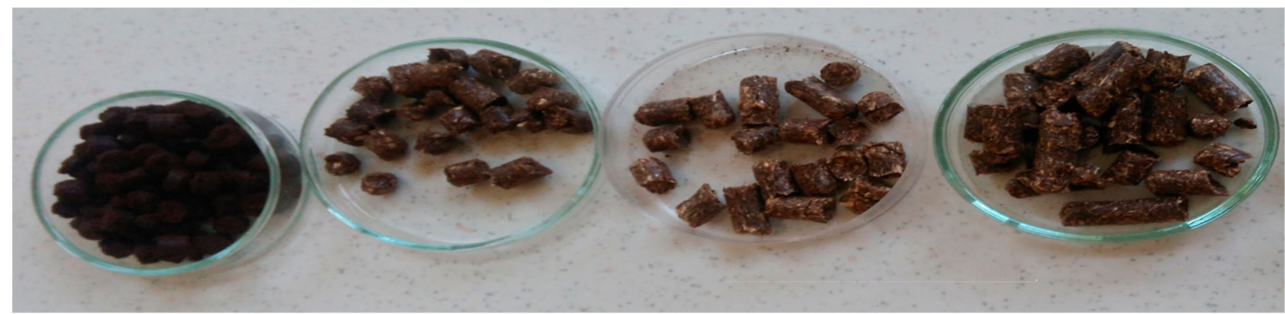

(a) (b) (c) (d)

Figure 2. Samples: (a) 100\% spent coffee grounds (SCG), (b) 50/50 SCG/sawdust, (c) 40/60 SCG/sawdust and (d) 30/70 SCG/sawdust.

Further, the SCG and sawdust were combined in the ratio 40/60, respectively, with an output moisture of $15 \%$. The produced pellets had a more cylindrical shape compared to the 50/50 sample, but this sample did not have the required strength and durability. This was checked by hand compression and compared to the strength of the wood pellets. The sample with a 30/70 SCG/sawdust ratio also had the same moisture content of $15 \%$ of input material. The result showed that pellets have strength properties close to the reference sample (wood sawdust pellets). Subsequently, the combustion tests were carried out in an automatic boiler (type Lokca, model Uspor, power $18 \mathrm{~kW}$ ).

\section{Experimental Research and Results}

\subsection{Calorific Values}

The calorific values of produced samples were measured using the LECO AC 500 device. This calorimeter is intended for the determination of the higher calorific value (HCV) of solids and liquids. The measurement of the HCV, the analysis of carbon, hydrogen, and nitrogen in the samples was performed. Its objective was to determine the hydrogen content of the produced pellets and to calculate the lower calorific value (LCV). The elemental compositions of the samples are given on a dry basis in Table 1. 
Table 1. Ultimate analysis of produced samples.

\begin{tabular}{ccccc}
\hline Parameter & \multirow{2}{*}{$\mathbf{1 0 0 \%}$ of SCG } & $\begin{array}{c}\mathbf{5 0} / \mathbf{5 0} \\
\text { SCG/Sawdust }\end{array}$ & $\begin{array}{c}\mathbf{4 0 / 6 0} \\
\text { SCG/Sawdust }\end{array}$ & $\begin{array}{c}\mathbf{3 0 / 7 0} \\
\text { SCG/Sawdust }\end{array}$ \\
\hline Total Carbon $(\%)$ & 54.56 & 52.69 & 52.13 & 51.29 \\
Total Nitrogen $(\%)$ & 17.78 & 46.87 & 50.64 & 61.66 \\
Total Hydrogen $(\%)$ & 7.44 & 6.99 & 6.89 & 6.74 \\
\hline
\end{tabular}

The collected results of studies compare the $\mathrm{C}, \mathrm{H}$ and $\mathrm{N}$ content of SCG (Table 2). It can be seen that the concentration of carbon (54.56\%) and hydrogen (7.44\%) of tested SCG are in agreement with reported ranges [1]. In the case of nitrogen, a higher content was recorded, compared to the values presented in Table 2. The fertilization of soil contributes to a higher content of nitrogen and increases its concentration in the coffee beans during growth.

Table 2. Comparison of ultimate analysis of SCG [3].

\begin{tabular}{cccc}
\hline & $\mathbf{C}(\mathbf{\%})$ & H (\%) & N (\%) \\
\hline \multirow{2}{*}{ SCG } & $46.42-71.6$ & $6.04-8.99$ & $2.03-15.5$ \\
\hline
\end{tabular}

Figure 3 shows calculated lower calorific values of samples; the highest value was obtained from $100 \%$ spent coffee grounds. As already mentioned, the LCV of dried coffee grounds ranges between 19.3-24.9 MJ.kg-1 [1] and the LCV of pure SCG in this study had $21.08 \mathrm{MJ} . \mathrm{kg}^{-1}$.

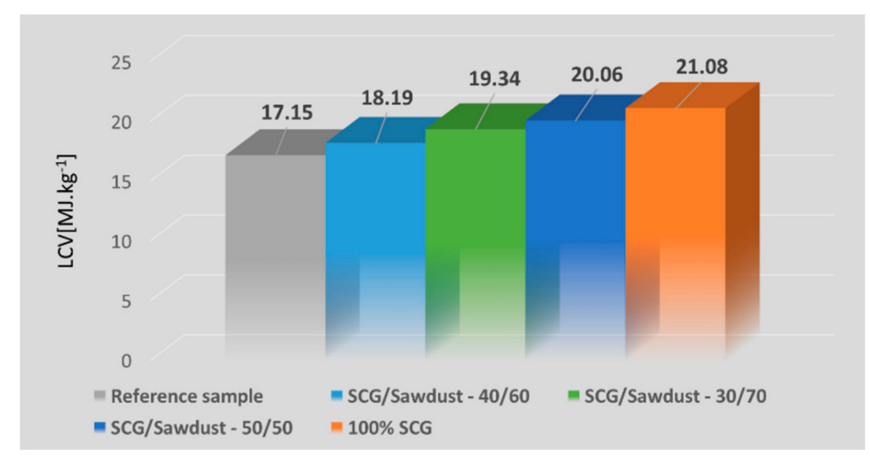

Figure 3. Lower calorific values of tested samples.

\subsection{The Boiler Measurements}

The boiler was placed on the scale and the supply of combustion air was provided by a ventilator. Emission probes were inserted to the outlet of the boiler, as well as a thermocouple and a draft pressure sensor. The actual boiler heat power was measured by a heat exchanger station and all data was recorded by the data logger (Figure 4). 


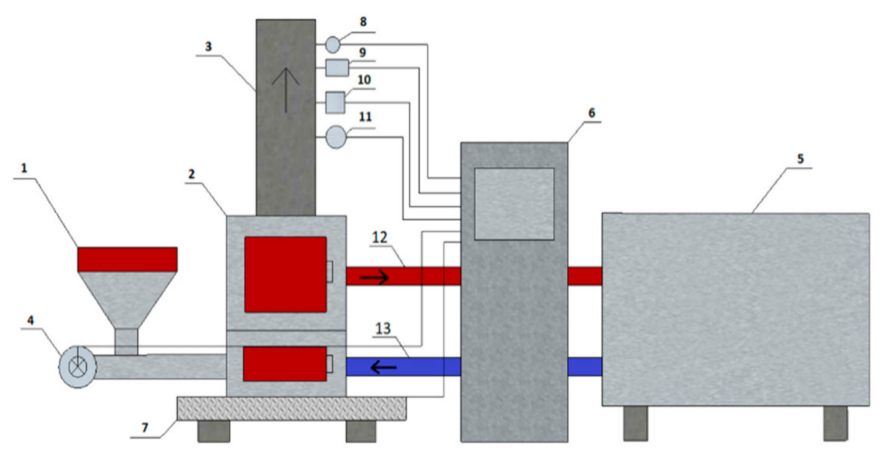

Figure 4. Scheme of experimental setup: 1-fuel tank, 2-pellet boiler, 3-chimney, 4-blower, 5heat exchanger station, 6-flue gas analyzer and data logger, 7-scale, 8-draft pressure sensor, 9and 10-mission probes, 11 - thermocouple, 12 - cold water, 13-hot water.

\subsection{The Analyses of Results}

Five samples were tested and each measurement lasted around $60 \mathrm{~min}$. Heat power and emissions measurements were performed continuously throughout the experiment. The concentration of $\mathrm{CO}$ and $\mathrm{CO}_{2}$ were measured in the flue gas and the results are shown in Figure $5 \mathrm{a}, \mathrm{b}$.

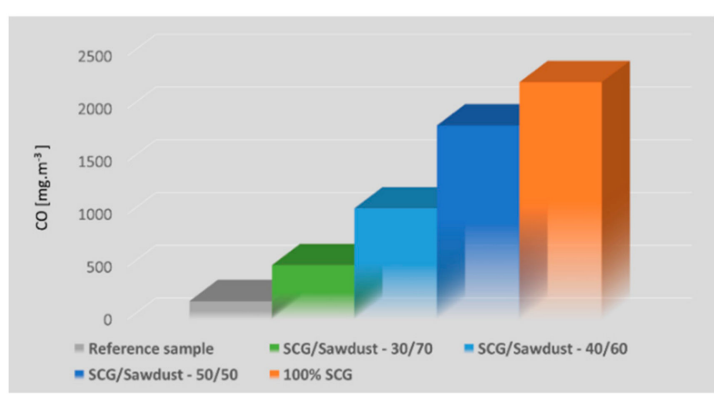

(a)

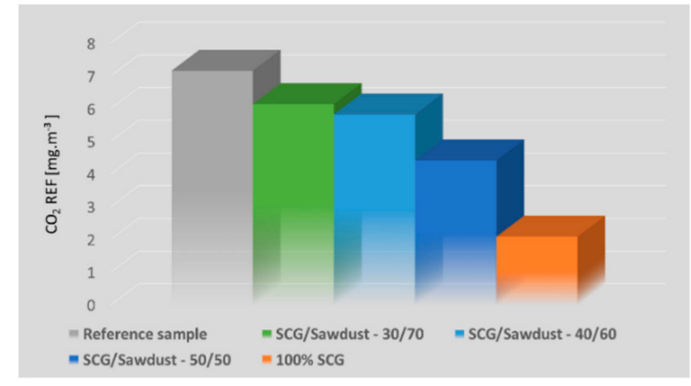

(b)

Figure 5. (a) Comparison of average $\mathrm{CO}$ emissions and (b) comparison of average $\mathrm{CO}_{2}$ emissions.

The highest CO concentrations were recorded in the 100\% coffee ground samples due to low pellet strength. This was checked by hand compression and compared to the strength of the wood pellets. Most of the sample volume was coffee powder, so the combustion was incomplete. In the 50/50 samples, similar results were observed. Also, these pellets did not have the required strength and therefore high $\mathrm{CO}$ emissions were recorded. In general, coffee pellets had incomparably higher $\mathrm{CO}$ emissions compared to certified wood pellets. The standard STN EN 303-5 2012 gives a maximum CO concentration of $3000 \mathrm{mg} \cdot \mathrm{m}^{-3}$ and all of the produced samples meet this standard. In contrast to CO, $\mathrm{CO}_{2}$ emissions were the lowest during $100 \%$ of SCG combustion, indicating precisely the incomplete combustion. Thus, most of the carbon contained in the coffee grounds has left the combustion chamber in the form of CO. Samples with ratios 40/60 and 30/70 had emissions comparable to wood pellets.

The formation of nitrogen oxides is accompanied mainly by high combustion temperature and chemical composition of the fuel. During the test of the 100\% SCG sample, incomplete combustion occurred, the combustion temperature was low, and this was reflected in low NO values (Figure 6a). Samples containing SCG and sawdust show comparable NO emissions since the nitrogen content in SCG $(17.78 \%)$ is higher than the concentration of nitrogen in wood pellets $(0.3 \%)$.

The performance of the boiler is mainly related to the quality of the fuel and proper settings of the heat source's control system. As mentioned above, the durability of the pellets from $100 \%$ of coffee grounds was low and the boiler heat power was four times lower compared to wood pellets (Figure 6b). 


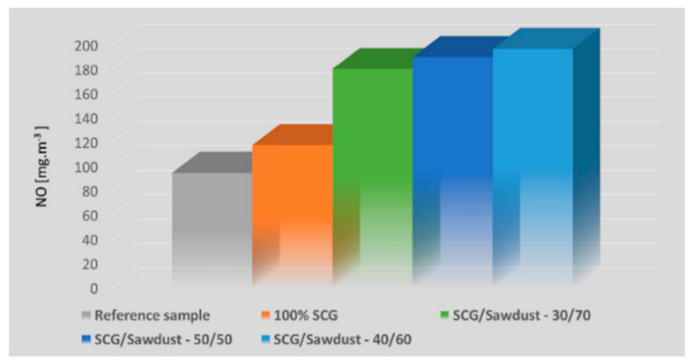

(a)

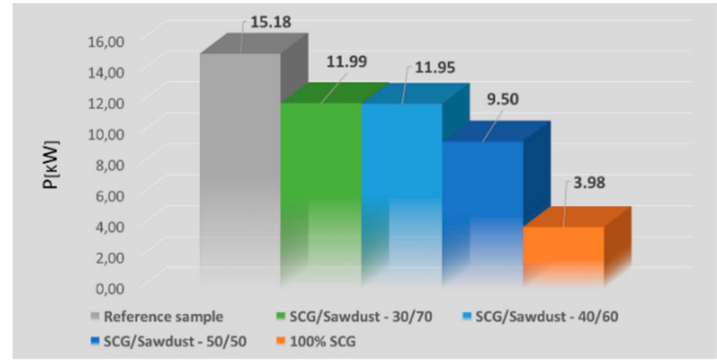

(b)

Figure 6. (a) Comparison of average NO emissions and (b) comparison of average heat power of the boiler.

\section{Discussion and Conclusions}

The chemical properties of coffee waste take the top position among the different types of material for wood pellet production and the short growing period for coffee beans is also an advantage of SCG compared to trees. Lisowski et al. [16] confirmed that the chemical composition of the SCG is a very good quality raw material for use as a biofuel, by highlighting that moisture had a greater and nonlinear effect on the density and strength of pellets than the height of the pelleting die.

This study showed that compared to the other samples studied here, the highest LCV was obtained from $100 \%$ SCG, due to the presence of a higher carbon content. The LCV of $100 \%$ SCG sample yielded about $21.08 \mathrm{MJ} . \mathrm{kg}^{-1}$ while the LCV of SCG/Sawdust (30/70) sample yielded $20 \mathrm{MJ} . \mathrm{kg}^{-1}$. However, the use of pure SCG can lower boiler efficiency along with an increase in particle and gas emissions [1,15]. The SCG mixed with pine sawdust $(50 / 50 \mathrm{wt} \%)$ could provide similar combustion parameters (emissions and boiler efficiency) to wood pellets and satisfy the NF agro-pellets standard (French standards), as stated by Atabani et al., 2019, Limousy et al., 2013 and Jeguirim, 2014 [1,13,17].

The study conducted by Kristanto and Wijaya [9] on the determination of the characteristics of SCG and CS and the effect of mixing SCG and CS on the quality of pellet fuel showed that the physical characteristics of CS were suitable for producing pellets with better density, durability, and combustion levels, but large amounts of CS in pellets potentially produces particulate and NOx emissions during combustion. Based on the German pellet standard DIN 51731, the sample with 75\% SCG, 20\% CS, and $5 \%$ artificial adhesive has the highest durability and optimum water content. This kind of sample had a constant flame and a decrease in temperature during the combustion process. The decrease in temperature caused by mixing CS with SCG was relatively constant because the pellet density affects combustion efficiency.

The aim of this research was to verify the potential of the coffee ground as an alternative fuel. The samples from $100 \%$ SCG proved the highest value of LCV, reduced durability, and therefore the results show low heat-power of the boiler and high CO emissions. The high concentration of carbon monoxide can be a result of incomplete combustion and a carbon content higher than 50\% of SCG. It has been found that the combustion of pure SCG decreases boiler efficiency and increases the concentrations of emissions, especially in the case of carbon monoxide [13]. Moreover, $\mathrm{CO}$ emission during combustion of $100 \%$ SCG (2248 mg. $\mathrm{Nm}^{-3}$ at $10 \% \mathrm{O}_{2}$ ) is lower than those obtained by Limousy et al. during pure SCG combustion (3069 mg.Nm ${ }^{-3}$ at $10 \% \mathrm{O}_{2}$ ) in a $12 \mathrm{~kW}$ boiler (Pellematic PES12_PVB 2000) [13]. Kang et al. combusted dried spent coffee ground and the results also confirmed the presence of the highest concentration of $\mathrm{CO}$ among the measured emissions [3]. Pilusa et al. reported that carbon monoxide from the combustion of already mentioned eco-fuel briquettes dominated in the flue gas [12]. Besides, CO is the most abundant gas in the flue gas and it is necessary to cut this emission. The 30/70 (spent coffee grounds/sawdust) sample appears to be the most ideal when compared to other analyzed samples, taking into account the measured performance of the boiler and emissions. For practical use of coffee grounds, it would be necessary to produce pellets with higher quality pelletizing machines in order to improve their strength and durability [18-20]. These parameters affect the reported emissions 
and heat power of the boiler. The combustion of SCG could be one of the options for utilization of coffee waste, based on its high calorific value [21], but according to the Paris Agreement, one of the key targets for 2030 is to reduce greenhouse gases and therefore, there is a need to find an environmentally acceptable solution.

Author Contributions: R.N.; experimental methodology, investigation, data collection, writing—original draft, M.M.T.; preparation of the testing equipment, formal analysis, writing and editing, D.J.; analysis of the data and validation. All authors have read and agree to the published version of the manuscript.

Funding: This research was funded by KEGA No. 038ŽU-4/2019 "Piping systems in heat supply" and VEGA No. 1/0479/19 "Influence of combustion conditions on the production of solid pollutants in small heat sources" and the project: CZ.02.1.01/0.0/0.0/16_019/0000753.

Conflicts of Interest: The funders had no role in the design of the study; in the collection, analyses, or interpretation of data; in the writing of the manuscript, or in the decision to publish the results.

\section{References}

1. Atabani, A.E.; Ala'a, H.; Kumar, G.; Saratale, G.D.; Aslam, M.; Khan, H.A.; Said, Z.; Mahmoud, E. Valorization of spent coffee grounds into biofuels and value-added products: Pathway towards integrated bio-refinery. Fuel 2019, 254, 115640. [CrossRef]

2. Tun, M.M.; Juchelková, D.; Raclavská, H.; Sassmanová, V. Utilization of biodegradable wastes as a clean energy source in the developing countries: A case study in Myanmar. Energies 2018, 11, 3183. [CrossRef]

3. Kang, S.B.; Oh, H.Y.; Kim, J.J.; Choi, K.S. Characteristics of spent coffee ground as a fuel and combustion test in a small boiler (6.5 kW). Renew. Energy 2017, 113, 1208-1214. [CrossRef]

4. Karmee, S.K. A spent coffee grounds based biorefinery for the production of biofuels, biopolymers, antioxidants and biocomposites. Waste Manag. 2018, 72, 240-254. [CrossRef] [PubMed]

5. Zuorro, A.; Lavecchia, R. Spent coffee grounds as a valuable source of phenolic compounds and bioenergy. J. Clean. Prod. 2012, 34, 49-56. [CrossRef]

6. Burniol-Figols, A.; Cenian, K.; Skiadas, I.V.; Gavala, H.N. Integration of chlorogenic acid recovery and bioethanol production from spent coffee grounds. Biochem. Eng. J. 2016, 116, 54-64. [CrossRef]

7. Kwon, E.E.; Yi, H.; Jeon, Y.J. Sequential co-production of biodiesel and bioethanol with spent coffee grounds. Bioresour. Technol. 2013, 136, 475-480. [CrossRef] [PubMed]

8. Somnuk, K.; Eawlex, P.; Prateepchaikul, G. Optimization of coffee oil extraction from spent coffee grounds using four solvents and prototype-scale extraction using circulation process. Agric. Nat. Resour. 2017, 51, 181-189. [CrossRef]

9. Kristanto, G.A.; Wijaya, H. Assessment of spent coffee ground (SCG) and coffee silverskin (CS) as refuse derived fuel (RDF). IOP Conf. Ser. Earth Environ. Sci. 2018, 195, 012056. [CrossRef]

10. Kansai, N.; Chaisuwan, N.; Supakata, N. Carbonized Briquettes as a Tool for Adding Value to Waste from Rain tree (Samanea Saman) and Coffee Ground/Tea Waste. Eng. J. 2018, 22, 47-63. [CrossRef]

11. Patcharee, P.; Naruephat, T. A Study on How to Utilize Waste Paper and Coffee Residue for Briquettes Production. Int. J. Environ. Sci. Dev. 2015, 6, 201. [CrossRef]

12. Pilusa, T.J.; Huberts, R.; Muzenda, E. Emissions analysis from combustion of eco-fuel briquettes for domestic applications. J. Energy South. Afr. 2013, 24, 30-36. [CrossRef]

13. Limousy, L.; Jeguirim, M.; Dutournie, P.; Kraiem, N.; Lajili, M.; Said, R. Gaseous products and particulate matter emissions of biomass residential boiler fired with spent coffee grounds pellets. Fuel 2013, 107, 323-329. [CrossRef]

14. Arce, M.E.; Saavedra, Á.; Míguez, J.L.; Granada, E.; Cacabelos, A. Biomass fuel and combustion conditions selection in a fixed bed combustor. Energies 2013, 6, 5973-5989. [CrossRef]

15. Moradian, F.; Pettersson, A.; Svärd, S.H.; Richards, T. Co-combustion of animal waste in a commercial waste-to-energy BFB boiler. Energies 2013, 6, 6170-6187. [CrossRef]

16. Lisowski, A.; Olendzki, D.; Swietochowski, A.; Dabrowska, M.; Mieszkalski, L.; Ostrowska-Ligeza, E.; Stasiak, M.; Klonowski, J.; Piatek, M. Spent coffee grounds compaction process: Its effects on the strength properties of biofuel pellets. Renew. Energy 2019, 142, 173-183. [CrossRef] 
17. Jeguirim, M.; Limousy, L.; Dutournie, P. Pyrolysis kinetics and physicochemical properties of agropellets produced from spent ground coffee blended with conventional biomass. Chem. Eng. Res. Des. 2014, 92, 1876-1882. [CrossRef]

18. Kantová, N.; Holubčík, M.; Jandačka, J.; Čaja, A. Comparison of Particulate Matters Properties from Combustion of Wood Biomass and Brown Coal. Procedia Eng. 2017, 192, 416-420. [CrossRef]

19. Palacka, M.; Vician, P.; Holubčík, M.; Jandačka, J. The Energy Characteristics of Different Parts of the Tree. Procedia Eng. 2017, 192, 654-658. [CrossRef]

20. Recycling Coffee Grounds into Biomass Pellets for Home Heating. Available online: https://wood-pellet-line. com/recycling-coffee-grounds-into-biomass-pellets-for-home-heating/ (accessed on 2 February 2020).

21. Sołowiej, P.; Neugebauer, M. Impact of coffee grounds addition on the calorific value of the selected biological materials. Agric. Eng. 2018, 20, 177-183. [CrossRef]

(C) 2020 by the authors. Licensee MDPI, Basel, Switzerland. This article is an open access article distributed under the terms and conditions of the Creative Commons Attribution (CC BY) license (http://creativecommons.org/licenses/by/4.0/). 